Estudios de

lingüística inglesa aplicada

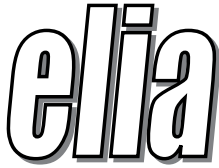

\title{
WHEN BILINGUALISM GOES BEYOND ONE'S EXPECTATIONS: THE LEARNING OF COGNATES AMONGST ADULT EFL STUDENTS
}

\section{CUANDO EL BILINGÜISMO SUPERA NUESTRAS EXPECTATIVAS: EL APRENDIZAJE DE COGNADOS EN ESTUDIANTES ADULTOS DE ILE}

\section{María Lorena Colombo López}

Consejería de Educación y Empleo (Junta de Extremadura) \& Doctoral student at UNED

marialorenacolombolopez@gmail.com

DOI: http://dx.doi.org/10.12795/elia.mon.2019.i1.05

Learning a foreign language (FL) is often perceived as a difficult objective to accomplish by adult learners. This is the case of Spanish adult learners who resume their Secondary Education studies and are required to study English as a mandatory subject, even if they have had little or no contact with the FL before. Therefore, neither educational authorities nor teachers support the implementation of a bilingual program since they consider these students'success in it would be limited.

Research suggests that vocabulary plays a crucial role in learners' FL overall competence and that adult beginners benefit from explicit training in vocabulary acquisition strategies. The present study examines the role of Spanish-English cognates and a technology-based approach in the improvement of learners' lexical knowledge. An experimental and a control 
group from the same adult education centre were recruited for the study. While the control group continued with regular instruction, the experimental group received teaching in cognate awareness as a learning strategy. Along with this training, participants completed a Massive Online Open Course (MOOC) focused on the self-study of 1,000 highly frequent English words, among which cognates played a salient role. Both groups completed a vocabulary test before and after the intervention period, with the experimental group significantly outperforming the control group. Therefore, as predicted by previous studies, explicit training in cognates fosters the acquisition of FL lexical competence by assisting the learning of less-proficient students, such as those enrolled in Adult Education.

Key words: FL, adult learners, vocabulary knowledge, cognate awareness.

Los adultos suelen considerar el aprendizaje de una lengua extranjera (LE) como un objetivo dificil de alcanzar. Este es el caso de alumnos españoles que retoman sus estudios de Educación Secundaria y cursan inglés de manera obligatoria, a pesar de su poco o nulo contacto previo con la LE. Así pues, ni las autoridades educativas ni los profesores apuestan por la implantación de un programa bilingüe al considerar que el éxito de estos alumnos en él sería limitado.

Las investigaciones sugieren que el vocabulariojuega un papel significativo en la competencia general de una LE y que los adultos noveles se benefician de la formación explícita en estrategias de adquisición de vocabulario. Este estudio examina el papel de los cognados español-inglés y la aplicación de un enfoque tecnológico en la mejora de la competencia léxica. Para el estudio, se tomaron dos grupos del mismo centro de adultos.

El grupo experimental recibió instrucción en el reconocimiento de cognados como estrategia de aprendizaje, junto con un curso en línea centrado en el autoaprendizaje de 1000 palabras frecuentes en inglés, entre las cuales los cognados tenían un papel significativo. Antes y después de la intervención, ambos grupos completaron un test de vocabulario que arrojó unos resultados significativamente superiores en el grupo experimental. Así pues, tal y como predijeron estudios anteriores, la enseñanza explícita de cognados fomenta la adquisición de la competencia léxica, ayudando en el aprendizaje a aquellos alumnos menos competentes, como los que cursan Educación de Adultos.

ELIA Mon. I, pp. 89-121 DOI: http://dx.doi.org/10.12795/elia.mon.2019.i1.05 
Palabras clave: LE, aprendices adultos, conocimiento de vocabulario, identificación de cognados.

\section{Introduction}

During this last decade, the unemployment rate has dramatically increased in Spain as an inevitable consequence of the global economic crisis, and this has had a major effect not only on the financial wellbeing of the Spanish population, but also on Spain's educational system as a whole. Indeed, the lack of job opportunities led to the enrolment of many adult learners in courses that could add to their previous studies, such as those offered by Vocational Training programs; however, others were forced to complete their Lower Secondary Education studies in order to obtain the Graduado en Educación Secundaria (hereafter referred to as Certificate of Secondary Education (CSE), which is regarded as a minimum requirement for most job positions in Spain. Indeed, it is precisely this last population group and their relationship with foreign language (FL) learning in the context of adult education that is the object of this research.

In this sense, it should be pointed out that the current curriculum for Lower Secondary Education for Adults (LSEA) establishes the study of English as a foreign language (EFL) as a mandatory subject; a situation that poses problems for students and teachers alike, since for the vast majority of learners enrolled in adult classes, English is a language with which they have had little or no previous contact before. For their part, EFL teachers must deal with this lack of knowledge or overall low proficiency while complying with the contents provided by the official curriculum, which they accommodate to their students' level.

The context being this, Spanish educational institutions have not supported any form of bilingual programs in LSEA; even though this modality has proved successful in other post-compulsory educational levels, such as Vocational Training. Nevertheless, this fact should not surprise us at all if we bear in mind the complexities that adult FL teaching and learning entail especially when one takes into account learners' diverse proficiency levels as well as their attitudes, motivations, and previous experiences with the FL.

ELIA Mon. I, pp. 89-121 DOI: http://dx.doi.org/10.12795/elia.mon.2019.i1.05 
The focus of this study was not to design a bilingual education programme for adults, but rather to analyse the issues that students and EFL teachers face from a pedagogical point of view, in order to devise a teaching approach that could contribute to addressing the needs of these beginner and false beginner students, and assist them on their learning of English as a mandatory subject within the LSEA curriculum. Therefore, considering the significant relationship between FL learners' lexical knowledge and their overall FL performance (Alderson, 2005; Laufer \& Goldstein, 2004; Meara \& Jones, 1988), a vocabulary-oriented approach was regarded as the most suitable to facilitate these students' learning process. Likewise, due to the students' low proficiency, a focus on SpanishEnglish cognates seemed convenient to enhance their vocabulary knowledge (Haastrup, 1991; Jessner, 1999; Otwinowska-Kasztelanic, 2009, 2016; Ringbom, 2007; Swam, 1997), while at the same time boosting their confidence when using the FL (Kroll, Michael, Tokowicz, \& Dufour, 2002; Lotto \& De Groot, 1998).

Therefore, two groups of adult students from the same adult education centre in Extremadura, Spain, were selected to investigate the role that Spanish-English cognates could play in the improvement of their FL vocabulary knowledge. More precisely, the main research question was: To what extent does the explicit teaching of cognates, together with the promotion of autonomous learning, improve adult learners' lexical knowledge? The hypothesis was that training students in the recognition of Spanish-English cognates as a learning strategy would enhance their mastery of the FL vocabulary, as well as improving their overall competence in the FL, contributing to their success in their LSEA studies.

\section{Theoretical Background}

\subsection{Adult Education in Extremadura, Spain}

In Spain, adult education should be understood within the wider framework of the so-called Lifelong Learning Strategy, which is promoted and funded by the European Commission, the Spanish Ministry of Education, and the regional education authority of each Autonomous Community. The main objective of this strategy is to support lifelong learning for Spanish citizens who are over 18 years old, by offering different types of publicly subsidised

ELIA Mon. I, pp. 89-121 DOI: http://dx.doi.org/10.12795/elia.mon.2019.i1.05 
provision, among which Lower and Upper Secondary Education, Vocational Training, Open Education, University Education, and Specialised Education are included. Indeed, the Organic Law 8/2013, on the Improvement of the Quality of Education (LOMCE) (MECD, 2013), states the need to guarantee adult citizens with universal and permanent access to learning which will enable them to improve their knowledge and skills for personal and professional development, favouring their incorporation into the labour market. Likewise, this law acknowledges the right for people over 16 to benefit from the LSEA provision, provided they have a labour contract which does not allow them to attend lessons at a regular high school, or if they have been recognised as high-performance sportsmen or sportswomen. The same applies to prison inmates. Moreover, education authorities are encouraged to organise these academic programmes in an open and flexible way that addresses adult students' skills, interests, and needs, without disregarding their learning style preferences and their personal and professional circumstances.

More precisely, Order 651/2017 (MECD, 2017) and Order of $1^{\text {st }}$ August (Gobierno de Extremadura, 2008) regulate LSEA at state level and regional level, respectively, establishing the guidelines and contents that constitute the curriculum to be taught. In this respect, several differences can be observed in terms of the organisation of LSEA studies if we compare them to those of regular Lower Secondary Education. First of all, in order to favour flexibility, students are given the option to enrol either in classroom-based or distance courses. In both cases, the courses are divided into four-month terms to facilitate the completion of the four courses needed to obtain the CSE in just two academic years. Likewise, the subjects are reduced to three, namely Scientific-Technological Studies, Social Sciences, and Communication Studies and the students may enrol in one, two or the three of them each term, depending on the time they have at their disposal, and taking into account whether they have had some subjects validated thanks to their previous studies in regular Lower Secondary Education. In this respect, older students who obtained their Certificate in Basic Secondary Education in the past can apply for the validation of the first two courses of the LSEA, which means that they can finish these studies in just one academic year.

Regarding the provision in Extremadura, there are 21 Adult Education Centres and other 36 smaller centres located in villages to 
address the needs of students from rural areas. Likewise, there are eight regular high schools which offer adult classes in the evening and other two educational institutions which offer these courses to inmates in the two prisons of the region.

Thanks to this educational offer which spreads wide across the region, during the 2017-2018 academic year, a total of 6,091 students enrolled in the courses to obtain the CSE, 3,874 of whom opted to attend regular classes and 2,217 decided to follow online courses (Plataforma Educativa Rayuela, 2018). Nevertheless, only 1,155 of the students, that is, $18.96 \%$ of the total number of learners, completed their studies and obtained the CSE. These figures are extremely worrying for educational authorities and adult education teachers alike, especially when taking into account data from the Spanish National Statistics Institute, which assures that during the first quarter of 2018, when the present study was carried out, there were 128,400 unemployed people (14.28\% of the total population) in Extremadura, 84,100 of whom were not in possession of the CSE (Economically Active Population Survey, 2018). This means that 65\% of the unemployed population did not have the minimum academic requirement to apply for a job. In turn, this fact brings to light the need for quality adult education which meets the demands and needs of this population group so as to enable them to return to the labour market as soon as possible.

\subsection{English as a Foreign Language within the Curriculum of Secondary Education for Adults}

After the previous presentation of the characteristics of adult education in Extremadura, it is not surprising that no form of bilingual education programme has been implemented at this level, even though the educational authorities have been supporting this type of education since the 20042005 academic year. In this respect, it seems reasonable not to advocate a bilingual programme if we take into account the aforementioned structure of the curriculum, with reduced contents in terms of time and number of subjects, as well as adult students' overall low proficiency in foreign languages. Nonetheless, both the national and regional laws which regulate the curriculum in LSEA include the compulsory study of EFL in order to develop a certain degree of communicative competence which will entitle

ELIA Mon. I, pp. 89-121 DOI: http://dx.doi.org/10.12795/elia.mon.2019.i1.05 
learners to more job opportunities in an ever-increasing global labour market. Even though the inclusion of EFL in the curriculum may seem an interesting proposal, it entails an array of difficulties on the part of adult students and EFL teachers for a number of reasons which are outlined as follows.

On the one hand, it is necessary to bear in mind the fact that the subject of EFL is integrated within the above-mentioned Communication Studies, which also comprises Spanish Language and Literature. In this respect, the Order of $1^{\text {st }}$ August (Gobierno de Extremadura, 2008) regulates Communication Studies to be taught for six periods of fifty-five minutes each per week, four of which should be devoted to Spanish Language and Literature, and only two to English. Most EFL teachers would agree that this is an insufficient number of classes per week for the students to attain certain competence in the FL. This lack of time is remarkably relevant in the case of older students who have never studied English before, mainly because until the 1980's, the trend among educational authorities in Spain was to promote the learning of French as a FL, instead of English. It is true that the official curriculum tackles these students' lack of knowledge by establishing EFL contents which are adapted for beginners and gradually become more advanced throughout the four courses. Nevertheless, teachers still have to deal with the difficulties faced by those students who resume their studies in the third course, after having had the first two courses of LSEA validated. For these students, learning English is an arduous task to accomplish, since their first encounter with the FL implies learning modal verbs, Present Perfect and Future tenses as well as using vocabulary related to media, Information and Communication Technologies, and the environment.

On the other hand, EFL teachers have to overcome another obstacle, since in all likelihood, they will have a mixed-ability class, composed of students with different levels of proficiency and varying learning rates. This may cause conflict between the students who have previously studied English in either regular Compulsory Secondary Education at high school or in LSEA in previous years, and those who are absolute beginners. Therefore, the EFL teacher has to find a balance between the teaching of elementary contents to accommodate to beginners' needs and the demands of more advanced students. Teachers' ability to deal with these issues is essential to avoid the high rates of withdrawal which are extremely common

ELIA Mon. I, pp. 89-121 DOI: http://dx.doi.org/10.12795/elia.mon.2019.i1.05 
among adult students; either because they think they cannot cope with the learning of English or because the latter may feel demotivated when attending lessons in which the teacher includes rather basic contents to adjust to other less proficient students.

As regards this last issue, adult education teachers are currently working with ever-increasing heterogeneous groups, which means that they do not only have to cater for their students' different levels of proficiency in the FL, but they must also take into account adult learners' general characteristics and individual differences. In this sense, teachers ought to make a comprehensive analysis of every student's personal characteristics, learning style preferences and, in our case, attitudes and previous experiences with the FL. It is fairly common to observe different levels of anxiety, fear, and low self-concept among adult FL learners; a situation which is partly due to folk wisdom's beliefs and prejudices. Indeed, apart from students' own self-concept of their capacities and difficulties, for years, the prevailing stance among second language acquisition (SLA) researchers has focused on adult learners' limitations due to their age and the alleged reduction in neural plasticity; a theory which was also supported by the Critical Period Hypothesis (Lenneberg, 1967). According to this hypothesis, there is an optimal period for language acquisition which ends around puberty; a phase which is also known for marking the beginning of a process of brain lateralisation, allowing for specialisation in the different skills in each of the hemispheres. This critical period has also been applied to SLA; its advocates arguing that the younger a person starts learning a FL, the more proficient he/she will become. By contrast, if someone begins the learning of a FL after puberty, it will be almost impossible for them to acquire native-like proficiency in that language, since, as Lenneberg (1967) argues, "automatic acquisition from mere exposure to a given language seems to disappear, and foreign languages have to be taught and learned through conscious and labored effort." (p. 176).

This idea has been so widespread that it has been settled among the general public, resulting in their belief that the learning of a FL is extremely difficult among the adult population. Nevertheless, recent technological advances in neuroimaging have allowed researchers to prove that neuroplasticity maintains its capacity for transformation and adaptation in mature brains (Hernandez, 2013; Li, 2014). Moreover, Singleton and Ryan

ELIA Mon. I, pp. 89-121ＤOI: http://dx.doi.org/10.12795/elia.mon.2019.i1.05 
(2004) state that "it has not been demonstrated that the diminishing plasticity of the brain is linked to processes specifically and exclusively relating to developments in respect of the specialisation of cerebral structures for language acquisition." (p.40). Thus, age cannot be considered the single crucial element involved in hindering FL acquisition. In line with this idea, researchers such as Dörnyei (2006) and Lightbown and Spada (2006) advocate other reasons which have a much more significant influence in learners' ultimate FL attainment; namely, affective variables, intrinsic, and extrinsic motivations, as well as attitudes towards the FL.

Following this, the role of teachers as facilitators of learning, instead of being authoritarian figures imposing contents and activities, is of foremost importance (Knowles, Holton, \& Swanson, 2005). Thus, teachers must promote a safe learning environment where students deal with content which is appropriate for their level of proficiency, without disregarding their concerns towards FL learning. Besides, they must provide students with the tools and strategies to overcome the difficulties they may encounter throughout this learning process.

\subsection{Learning Strategies and Vocabulary Learning: A Focus on Cognates}

It is widely accepted that adult learners utilise learning strategies to compensate for their limitations when learning a FL. On the one hand, they put into practice cognitive strategies, which refer to the "manipulation or transformation of the target language by the learner" (Oxford, 1990, p. 43), including: repetition, translation, comparing FL and first language (L1) items, summarising, and laying emphasis on certain FL forms. On the other hand, learners may resort to metacognitive strategies, as an "ability to monitor and evaluate their own progress, better time management skills and knowledge of learning strategies" (Griffiths, 2008, p. 40).

As regards strategy use, a striking difference can be observed between adult students who enrol in Vocational Training or university courses and those who attend LSEA classes. In this last case, their underlying motivation is to obtain a certificate which would allow them to find a job, rather than being guided by a desire for personal and professional growth. Besides, these learners are not usually able to work autonomously

ELIA Mon. I, pp. 89-121ＤOI: http://dx.doi.org/10.12795/elia.mon.2019.i1.05 
or use learning resources on their own. Thus, the above-mentioned strategies prove useless, unless we teach learners how to benefit from them.

Here again, the teacher's role as a facilitator of knowledge (Knowles et al., 2005) remains particularly important and strategy training becomes a major component in his/her teaching activity. Moreover, adopting appropriate strategies does not just affect the learners' progress, but, as stated by Allwright and Little, "can also enable students to become more independent, autonomous, lifelong learners" (as cited in Oxford, 2003, p. 9).

With this strategy training in mind, it must be highlighted that "cross-linguistic similarity is an important variable in the use of learning strategies" (Ringbom, 2007, p. 104). This is of foremost importance in this teaching-learning context, given the similarities Spanish shares with English in terms of vocabulary. More precisely, the focus will be on cognates, described as words with a common etymological origin by historical linguists and as words with identical orthography and meaning by psycholinguists (Lemhöfer \& Dijkstra, 2004). For their part, language acquisition researchers favour a more general definition focused on the orthographic overlap between words, disregarding their phonology (Schepens, Dijkstra, \& Grootjen, 2012), or simply as "words with similar form and meaning in two languages" (De Bot, 2004, p.19).

For the purpose of this study a broader definition has been adopted, encompassing all the aspects of the previous definitions:

[...] words similar in their form and meaning, which have descended from a common parent word, have been borrowed from Lx language to Ly language, or are internationalisms borrowed independently by languages Lx, Ly and Lz. They do not have to be identical since they have been adapted to fit the rules of spelling, phonology and morphosyntax of Lx, Ly and Lz. (Otwinowska-Kasztelanic, 2016, p. 46)

Even though cognates have not received much attention from SLA research, the role they play in this field should be taken into consideration. Indeed, authors such as Schmitt (1997) consider the use of cognates as a FL learning strategy. He argues that cognates can be included within what he calls determination strategies, which are a type of discovery strategies, used by learners to discover the meaning of words which they encounter 
for the first time. He states that "if the target L2 is closely related to a learner's L1, cognates can be an excellent resource for both guessing the meaning and remembering new words" (p.209). In this respect, Nash (1997) compiled approximately 20,000 Spanish-English cognates, a figure which should not be underestimated due to the learning potential it entails.

Recent research has shown that there is a clear facilitation effect when cognates are included in the study of a FL, boosting learners' lexical knowledge, especially if the target language is related to a previously learnt one (Helms-Park \& Dronjic, 2016). Cognates were recognised and translated faster than non-cognates in studies carried out by Dijkstra, Grainger, and Van Heuven (1999), Kroll and Sunderman (2003), Lotto and De Groot (1998), and Peeters, Dijkstra, and Grainger (2013).

Besides, it has been demonstrated that cognates are easier to learn and less prone to attrition than non-cognates (De Groot \& Keijzer, 2000). The authors suggest two possible reasons for such an advantage:

(a) Due to the form overlap between cognate translations and the absence of such overlap between noncognate translations, in the case of cognate learning there is in fact less to learn than when noncognates are presented for learning. (b) Whereas in noncognate learning new entries have to be created in memory, cognate learning may only involve adding new information to, or adapting, memory representations that already existed in memory prior to learning. The former process may be more demanding than the latter, thus causing the disadvantage for noncognates. (pp.33-34)

Overall, research has shown that cognates may contribute to enhancing learners' FL lexical knowledge, especially in the case of less proficient learners, since there is solid evidence supporting their tendency to transfer linguistic items from their L1 (Jarvis \& Pavlenko, 2007; Ringbom, 2007). In this respect, Ringbom (1987) assured that "the less the learner knows about the target language, the more he is forced to draw upon any other prior knowledge he possesses" (p. 155). Likewise, in their study, Kroll et al. (2002) concluded that less fluent learners benefited more from cognates, arguing that "during early stages of acquisition, lexical transparency provides a means to utilize highly available information in L1 to facilitate the processing of L2" (p. 152). In this way, cognates represent an asset which can undoubtedly boost learners' confidence in their use of the FL.

ELIA Mon. I, pp. 89-121ＤOI: http://dx.doi.org/10.12795/elia.mon.2019.i1.05 
Nonetheless, Schmitt (1997) admitted that students do not automatically recognise cognates as equivalent words in their L1, a problem which may be due to "the perceived distance between languages" (Ringbom, 2007, p. 86). In line with this idea, other researchers have assured that, although English shares many cognates with Romance languages, students generally find it difficult to notice them (Kellerman, 1983; Lightbown \& Libben, 1984; Nagy, García, Durgunoglu, \& Hacin-Bhatt, 1993). Thus, students need to be trained in the identification and use of cognates if they are to benefit from them (Dressler, Snow, August, \& White, 2011; Haastrup, 1991; Helms-Park \& Perhan, 2016; Ringbom, 2007; Tréville, 1996).

Once students are taught how cognates work, they can incorporate them into their learning strategies repertoire in order to expand their vocabulary. In Wilkins' words (1972), “while without grammar very little can be conveyed, without vocabulary nothing can be conveyed" (pp. 111112). These words stand in sharp contrast to the marginal importance given to vocabulary learning during the second half of the twentieth century, the reason why Meara (1980) described it as a Cinderella subject within the field of FL teaching and learning.

Milton (2009) acknowledges three possible reasons to explain this neglect. Firstly, the influence structural linguistics exerted in language teaching by focusing on language rules and systems and leaving aside the words needed for those rules to develop. Secondly, the belief among all the stakeholders in the FL learning-teaching process that it is possible for a learner to achieve a high degree of FL proficiency with a relatively small vocabulary. Finally, he mentions Ellis' argument that "most L2 vocabulary is learned incidentally" (as cited in Milton, 2009, p. 2).

By contrast, recent research has proved that vocabulary cannot be disregarded, but rather considered a major component in the development of other language skills, including accurate communication. Meara and Jones (1988) and Laufer (1992) found a significantly high correlation between vocabulary knowledge and other aspects of language proficiency. Moreover, Laufer and Goldstein (2004) investigated the relationship between various aspects involved in the vocabulary knowledge of $435 \mathrm{ESL}$ learners and their class grades, finding that a $42.6 \%$ of the total variance in class grades was attributable to the participants' knowledge of the link between the form and meaning of the words under study. This allowed the 
authors to state that there is "an impressive contribution of a solid lexical knowledge to overall language success. (...) vocabulary has been shown to be associated with reading, writing and academic success" (pp. 423-424).

In line with this research, Alderson (2005) investigated the relationship between learners' lexical knowledge and their overall language performance. His results showed that vocabulary tests scores were significantly correlated to those obtained in the reading, listening, writing, and grammar tests, suggesting that vocabulary knowledge was responsible for $37-62 \%$ of the variance in those scores. As Alderson (2005) concluded, the "development in these three macro skills is parallel to, and conceivably caused by, development in a learner's vocabulary, both in terms of the size of the vocabulary and the quality of the learner's understanding and use of vocabulary" (p. 207). A similar high correlation was also found in a study which examined the relationship between vocabulary size and reading skill in the second language (Albrechtsen, Haastrup, \& Jenriksen, 2008).

The present study examined the effects of cognate training on learners' lexical knowledge as a learning strategy which could boost their overall FL competence. Moreover, additional vocabulary material was included in the form of a MOOC (Chacón-Beltrán, 2014; 2018) in order to promote autonomous learning, by providing learners with the tools to study at their own pace, collaborating with other EFL learners, and being responsible for the progress they made. This study aims to contribute with new data obtained from adult low-proficiency EFL learners to the field by analysing whether their vocabulary knowledge can be enhanced by a cognate-focused pedagogical intervention.

\section{Methodology}

\subsection{Participants}

A total of 32 students from two third-year groups of an adult education centre in Extremadura took part in this study. The experimental group received explicit instruction in cognate awareness as a learning strategy, coupled with the completion of a Massive Online Open Course (MOOC) called 'Empieza con el inglés' or 'Beginner English' (UNED Abierta, 2018) offered by UNED (Universidad Nacional de Educación a Distancia),

ELIA Mon. I, pp. 89-121 DOI: http://dx.doi.org/10.12795/elia.mon.2019.i1.05 
which is Spain's national distance education university. Meanwhile, the control group continued with regular instruction of EFL. There were 16 students in the control group ( 7 female and 9 male) and their average age was 32.56; the experimental group was also composed of 16 students (6 female and 10 male) and their average age was 29.1 .

All the participants in the study spoke Spanish as their L1 and they studied English as a FL. They were evaluated as false beginners who had spent an average of 8.06 and 7.62 years (control and experimental group, respectively) learning English in formal education. They reported an exposure to English of about three hours per week during those years. None of them had travelled to or stayed in an English-speaking country and the only contact they had had with the FL before the study was through listening to music on the radio or reading instructions on the Internet, such as in the case of videogames.

Overall, students showed fairly positive attitude and high motivation with respect to interest in the FL, motivational intensity, class anxiety, teacher evaluation, attitudes toward learning English, attitudes toward English-speaking people, desire to learn English, course evaluation, use anxiety, integrative orientation, and instrumental orientation. Figures 1 and 2 summarise the results which were obtained from the Attitude and Motivation Test Battery (AMTB) (Gardner, 2004) in the present study:

Informants were given an outline of the study and a consent form to sign, accepting their participation in the study. Participants in the experimental group were explained the aim of the pedagogical intervention in more detail, while those in the control group were just told that the study consisted in evaluating their vocabulary knowledge at the beginning and end of the course to check whether there was any improvement. Likewise, students were reassured that their participation in the study would not have any influence on their class grades. 


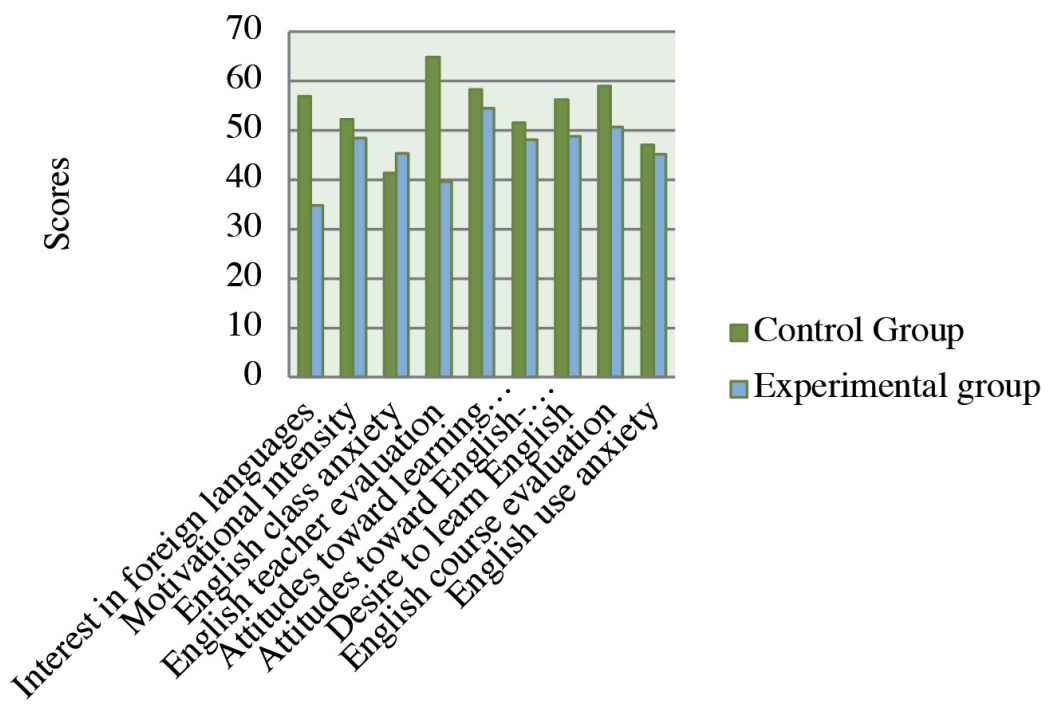

Figure 1. Comparison of AMTB scores between the control and experimental groups.

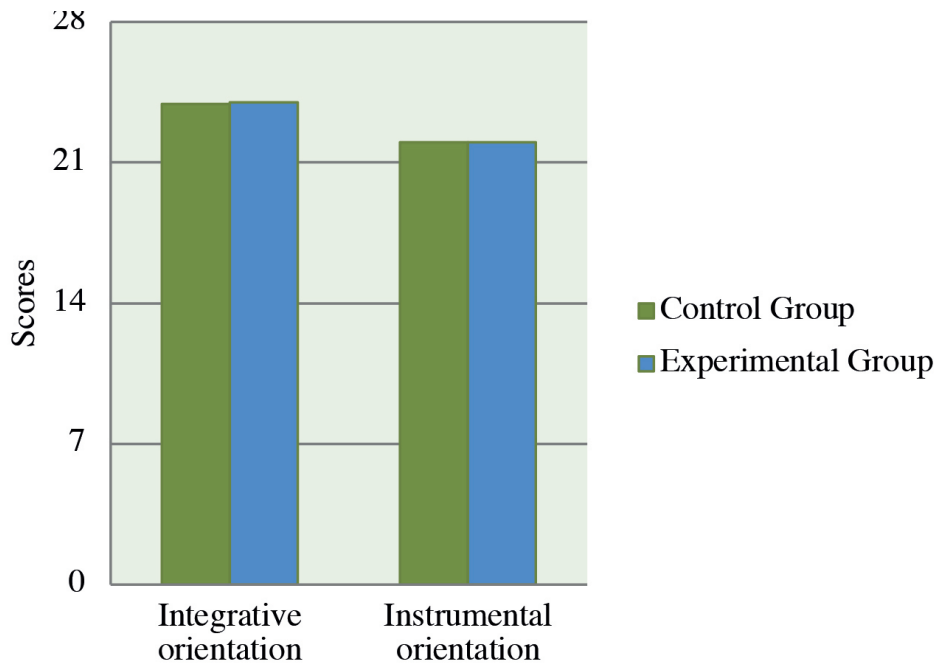

Figure 2. Comparison of scores regarding integrative and instrumental orientation across groups.

ELIA Mon. I, pp. 89-121 DOI: http://dx.doi.org/10.12795/elia.mon.2019.i1.05 


\subsection{Materials, Design and Procedure}

Prior to the beginning of the pedagogical intervention, all the informants took an adapted version of the Language Contact Profile (LCP) (Freed, Dewey, Segalowitz, \& Halter, 2004) and the Spanish version of the AMTB, with questions in the form of Likert scales (Gardner, 1985, 2004), to ensure their homogeneity with respect to their previous experience with the FL as well as their motivations and attitudes towards its learning.

Regarding the LCP, students were asked to include their full name so that the researcher could contact them if necessary. These data were later assigned codes like 'student1', 'student2', etc., in order to preserve students' identity. By contrast, the AMTB was anonymous to allow for students' answers to be as honest as possible, making them feel free to answer vexed questions concerning the English subject and their teacher.

After completing the LCP and the AMTB, both groups took the $X$ Lex vocabulary test (Meara \& Milton, 2003) (pre-test) to check their initial vocabulary knowledge and confirm their homogeneity in this respect. According to its authors, this test provides an overview of the vocabulary known by a learner and an overall vocabulary size estimate. The test consists of a computerized checklist which measures the vocabulary known at the first five 1,000 frequency bands. In order to complete it, students are presented with words and they have to decide whether they know their meaning by clicking on a smiley face if they do or on a sad face if they do not. There are 120 words in total, 20 words for each frequency bands, plus 20 pseudo-words to compensate for the times learners randomly click on the smiley face button. Learners are warned about the existence of these imaginary words. At the end of the test, the program produces a raw score, with the number of words the learner claims to know, and an adjusted score, resulting from the deduction of the non-words selected by the learner. Both scores range from 0 to 5,000 points and it is the adjusted score that is considered. Regarding the profile, it shows five bars representing the words known in each frequency band, and another bar to indicate the level of errors. In general, learners' profiles (See Appendix A) steadily slope downward, showing greater knowledge of words in the first band than in the fourth or fifth ones.

The choice of this receptive vocabulary test was motivated by three reasons: the reliability of the test, the role of passive vocabulary in learners' 
FL competence, and the students' proficiency. Firstly, the $X_{-}$Lex test presented good validity and reliability in previous studies with EFL students at different levels of proficiency (Miralpeix, 2012; Miralpeix \& Muñoz, 2018). Likewise, receptive vocabulary size is generally accepted to be a good indicator of learners' overall FL proficiency; as Meara (1990) assured, "passive recognition is the basic, rock bottom skill on which all the other skills rest" (p. 4). Finally, the test was considered suitable for low-proficient students since it evaluates just the first five frequency bands and it only requires the learner to decide whether he/she knows the meaning of the word. This is a relatively easy and quick task (it usually takes less than 15 minutes) if we compare it to other receptive vocabulary tests, such as the Vocabulary Levels Tests (Schmitt, Schmitt, \& Clapham, 2001), which implies reading definitions. Nation's Vocabulary Size Test (Nation \& Beglar, 2007) tests 14 frequency bands and was considered rather long and complex for beginners. Similarly, the $V_{-} Y e s N o$ (Meara \& Miralpeix, 2017) covers the first ten frequency bands (scores from 0 to 10,000), its results being unreliable below 1,500 points, which is what beginners usually score according to its authors.

The profiles produced by the $X$ Lex program indicated that all participants showed the expected pattern, with less correct answers as they faced words pertaining to higher frequency bands. Likewise, the results from this vocabulary test showed that although the control group's performance was slightly better $(\mathrm{M}=1706.25, \mathrm{SD}=736.63)$ than the experimental group $(\mathrm{M}=696.88, \mathrm{SD}=605.66)$, the difference was not statistically significant: $t(30)=-.039, p=.969$. Thus, we could assume that both groups were homogeneous in terms of their initial overall vocabulary knowledge.

Having gathered information about students' personal data, previous language contact, attitude and motivation towards the FL, and their vocabulary size estimate, it could be concluded that the groups were comparable before the implementation of the pedagogical intervention. In this respect, the control group continued with regular instruction. By contrast, the experimental group received 14 weeks of teaching in cognateawareness raising by a different teacher, who was also the main researcher in the present study. Along with this training, these students worked on 1,000 highly frequent English words drawn from a MOOC (ChacónBeltrán 2014, 2018), among which cognates played a salient role. Both

ELIA Mon. I, pp. 89-121 DOI: http://dx.doi.org/10.12795/elia.mon.2019.i1.05 
groups worked on the materials especially developed to teach the curriculum for LSEA (Consejería de Educación de la Junta de Extremadura, 2008).

In the experimental group, the teacher focused on raising awareness of word patterns and similarities between Spanish and English through explicit teaching, making students notice the existence of cognates on every occasion possible. Special attention was paid to word patterns, such as affixes. Learners were also encouraged to find cognates in texts, underlining them and then commenting on the similarities and differences with respect to their Spanish equivalents. There were often opportunities for discussion about word origins and how words change over time, mainly due to adaptations and the influence from other languages with which they come into contact. Likewise, the teacher brought other resources into the classroom, such as Youtube videos (Learn Spanish with Sebas, 2017; Lirica-Learn Spanish with Music, 2017) with examples and explanations of cognate patterns; for instance, English words ending in -ous, -ct, and -ance change to -oso, -cto, and ancia, respectively (as in mysteriousmisterioso, insect-insecto, and distance-distancia). Students also took part in games which involved matching English and Spanish cognates written on separate sheets of paper.

Moreover, other tools were introduced into the lessons, namely an online dictionary (WordReference, 2009), a dictionary of Spanish cognates (Nash, 1997), and a browser extension called The Cognate Highlighter Browser (Google Chrome, 2016), which once installed on a computer, allows the browser to highlight all the Spanish-English cognates (see Appendix B). This proved to be an interesting and extremely useful tool to teach cultural content because it made the students aware of the large proportion of English words which are similar to Spanish, as well as making them realise that they could handle authentic texts in English despite their low proficiency. This undoubtedly boosted their confidence in their use of English and encouraged them to search for more information and news from different English-speaking countries on their own.

Nevertheless, students were also warned about the existence of deceptive cognates or false friends, that is, words which have a formal overlap but differ semantically (as in Spanish actual $\neq$ English actual). This is an aspect to be taken into account, especially when teaching low proficient students, since they have "a tendency to generalize equivalences

ELIA Mon. I, pp. 89-121ＤOI: http://dx.doi.org/10.12795/elia.mon.2019.i1.05 
and to use this principle in comprehension and production" (Schmitt, 1997 p. 97). Therefore, apart from teaching the commonest false friends in English, special attention was paid to those deceptive cognates appearing in texts and activities, as well as those which emerged from their own oral and written productions in class.

This cognate approach was also supplemented by the materials provided by the aforementioned MOOC (Chacón-Beltrán 2014, 2018), which focuses on the study of 1,000 common English words throughout five thematic modules. These words were discussed both in writing and in video recordings, accompanied by Spanish translations and explanations about their formal cross-linguistic similarities (see Appendix C). The MOOC also included individual and cooperative assessment in which course participants would contribute to assessing their peers' tasks. In this respect, it must be highlighted that most participants in the study did not have a computer or Internet connection at home, so they followed the course by watching the videos in class, participating in the practice tasks in small groups, and completing peer assessment activities in writing. Regarding the complementary material, learners were provided with a booklet with the 1,000 words and their pattern rules so that they could study them at home.

Immediately after the end of the pedagogical intervention, the $X_{-}$ Lex test (post-test) was administered to both groups in order to examine whether the participants in the experimental group had benefited from the pedagogical intervention in terms of their overall lexical knowledge.

\subsection{Data Analysis}

In the present study, qualitative data were gathered from the LCP, and quantitative data were obtained from the AMTB in the form of Likert scales. Besides, the quantitative data from the $X_{-}$Lex tests were analysed using SPSS (Statistical Package for the Social Sciences) v. 24. An independent-samples t-test was carried out between the control group and the experimental group in order to examine the differences in the gain scores of both groups (post-test scores minus pre-test scores). Furthermore, paired-samples t-tests were conducted to analyse the progression of each group from the pre-test to the post-test.

ELIA Mon. I, pp. 89-121 DOI: http://dx.doi.org/10.12795/elia.mon.2019.i1.05 


\section{Results of the Study}

The post-test was administered to both groups immediately after the end of the intervention period and its results were examined in relation to those obtained in the pre-test. Table 1 provides an outline of the mean scores obtained by each group in the pre-test and post-test.

\begin{tabular}{|c|c|c|c|c|}
\hline & \multicolumn{2}{|c|}{$\begin{array}{c}\text { Control group } \\
(\mathrm{N}=16)\end{array}$} & \multicolumn{2}{c|}{$\begin{array}{c}\text { Experimental group } \\
(\mathrm{N}=16)\end{array}$} \\
\hline & $\mathrm{M}$ & $\mathrm{SD}$ & $\mathrm{M}$ & $\mathrm{SD}$ \\
\hline Pre-test & 1706.25 & 736.63 & 1696.87 & 605.65 \\
\hline Post-test & 1593.75 & 922.11 & 2487.50 & 664.2 \\
\hline
\end{tabular}

Table 1. Intergroup comparison of the average scores obtained in the pre-test and post-test

In the same way, Figure 3 shows the progress observed in each of the groups over time, focusing on the average scores they obtained in the pretests and the post-tests.

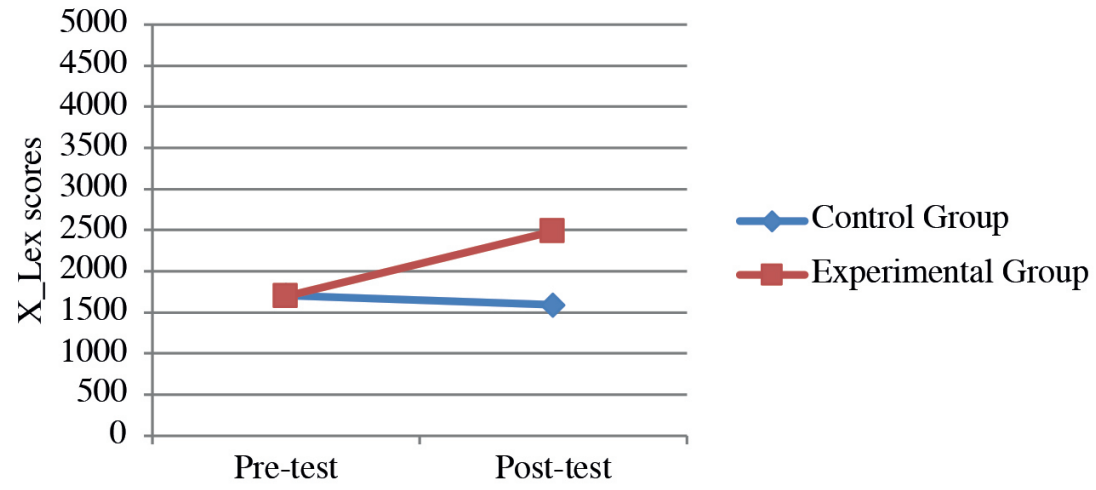

Figure 3. Group progress from pre-test to post-test.

Once the gain scores were calculated and an independent-samples t-test was run, a statistically significant difference $(t(30)=6.351, p=.000)$

ELIA Mon. I, pp. 89-121 DOI: http://dx.doi.org/10.12795/elia.mon.2019.i1.05 
was observed between the gain scores in the control group $(M=-112.50$, $\mathrm{SD}=484.25)$ and those obtained in the experimental group $(\mathrm{M}=790.63$, $\mathrm{SD}=298.45)$.

As far as intragroup analysis is concerned, paired-samples t-tests were carried out to examine the progress made within each group. Regarding the control group $(M=1593.75, S D=922.11)$, there were not statistically significant differences between the scores in the pre-test and the post-test: $t(15)=.929, p=.367$. By contrast, and as it was expected, the students in the experimental group showed an improvement in their vocabulary post-test scores $(\mathrm{M}=2487.50, \mathrm{SD}=664.20)$ which was statistically significant: $t(15)=-10.59, p=.000$ (see Table 2 ).

\begin{tabular}{|c|c|c|c|c|c|c|}
\cline { 2 - 7 } \multicolumn{1}{c|}{} & \multicolumn{2}{c|}{ Pre-test } & \multicolumn{2}{c|}{ Post-test } & \multicolumn{2}{c|}{ t-test } \\
\cline { 2 - 7 } \multicolumn{1}{c|}{} & $\mathrm{M}$ & $\mathrm{SD}$ & $\mathrm{M}$ & $\mathrm{SD}$ & $t$ & $p$ \\
\hline $\begin{array}{c}\text { Control group } \\
(\mathrm{N}=16)\end{array}$ & 1706.25 & 736.63 & 1593.75 & 922.11 & .929 & .367 \\
\hline $\begin{array}{c}\text { Experimental } \\
\text { group (N=16) }\end{array}$ & 1696.87 & 605.65 & 2487.50 & 664.2 & -10.59 & $* .000$ \\
\hline
\end{tabular}

$* p<0.05$

Table 2. Intragroup comparison of the average scores obtained in the pre-test and post-test

\section{Discussion}

In this study the research question was to discover whether an explicit cognate-awareness raising strategy and the promotion of autonomous learning could lead to an improvement in adult EFL learners' vocabulary knowledge. The results obtained confirm that the pedagogical intervention did have an effect on the experimental group's $X$ Lex gain scores. Specifically, these results suggest that when a group of adult students receive explicit training in Spanish-English cognate awareness, accompanied by autonomous learning of carefully selected words which also include cognates, their vocabulary scores are higher than those obtained by a group which does not receive any intervention. In this 
respect, the comparison of the gain scores obtained by both groups showed that the treatment in the experimental group resulted in an improvement of $46.6 \%$ in their post-test scores $(\mathrm{M}=790.63)$. By contrast, this progress could not be observed in the control group; indeed, the results showed an average decrease of 112.5 points in the post-test.

These results are in accordance with previous studies which proved that the explicit teaching of cognates helps learners in their attempts at mastering FL vocabulary (Dressler et al., 2011; Helms-Park \& Perhan, 2016; Holmes \& Ramos, 1993; Tréville, 1996). Moreover, significant importance is given to making students aware of cognateness so that they can incorporate it into their metalinguistic awareness and use it as a vocabulary learning strategy (Haastrup, 1991; Jessner, 1999; OtwinowskaKasztelanic, 2009; Ringbom, 2007; Swam, 1997).

It must be highlighted that the present study focused on a specific group of adult population which differs considerably to that addressed by other studies which examined the role of cognates in FL learners; namely, in false beginner teenagers (Dressler et al., 2011), university-level beginners and false beginners (Tréville, 1996), English-for-Academic-Purposes students (Helms-Park \& Perhan, 2016; Holmes \& Ramos, 1993), and a range from total beginners to advanced learners (Otwinowska-Kasztelanic, 2009). Nevertheless, in all these cases, an intervention with explicit teaching of cognates had a positive effect on students at lower stages of learning. Therefore, the results of this study seek to contribute to previous research by acknowledging the benefits of such a teaching strategy in adult beginners and false beginners with distinct personal and academic characteristics, a specific population which no study has examined before.

\section{Conclusions and Further Research}

Overall, adult beginners and false beginners seem to be ideal candidates for a cognate-focused pedagogical intervention, since low-proficient learners are the ones who benefit the most from an explicit focus on cognates, especially if we bear in mind that learners at these early stages rely much more on their L1 (Jarvis \& Pavlenko, 2007; Kroll et al., 2002; Ringbom, 2007). In this respect, implementing a vocabulary learning strategy based on Spanish-English cognates boosts their confidence in 
using the FL (Kroll et al., 2002; Lotto \& De Groot, 1998) and expands their learning strategies repertoire, making them aware of the importance of developing learning autonomy. Students become responsible for their own progress in the FL, choosing the strategies and the tools which best suit their learning preferences. Likewise, given the fact that students' lexical competence contributes to a great extent to the enhancement of their overall FL competence, this intervention may be regarded as significantly beneficial for learners studying English as a mandatory subject within the SLEA curriculum.

One of the limitations of this study was the distinct profile of the participants and their number, mainly due to high dropout rates among adult students. Thus, future research should include a larger sample of learners. Another limitation to be taken into account is the fact that the students in the experimental group worked with a wider range of appealing learning instruments, such as a MOOC, games and videos, resulting in a higher exposure to the FL. Therefore, perhaps the groups were not balanced in this respect. Likewise, students' attitude and motivation towards the learning of English should be re-examined, since it is possible to obtain different results from learners who may not be as interested in the study of the FL as these participants were. Finally, more research is needed to evaluate the role of phonology in the identification and use of cognates, although, in the case of Spanish-English pairs, it is expected to be less relevant than their orthographic overlap.

As a conclusion, in the light of these findings, it seems sensible to adopt an explicit vocabulary approach with a focus on cognates when teaching low-proficient students whose L1 shares a great number of crosslinguistic similarities with their target language. This is a valuable asset which should not be underestimated, especially when teaching English to Spanish adult learners in the context of LSEA courses.

\section{References}

Albrechtsen, D., Haastrup, K., \& Henriksen, B. (2008). Vocabulary and writing in a first and second language: Process and development. Basingstoke: Palgrave Macmillan.

ELIA Mon. I, pp. 89-121ＤOI: http://dx.doi.org/10.12795/elia.mon.2019.i1.05 
Alderson, J.C. (2005). Diagnosing foreign language proficiency: The interface between learning \& assessment. London: Continuum.

Chacón-Beltrán, R. (2014). Massive online open courses \& language learning: The case for a beginners' English course. Procedia-Social \& Behavioral Sciences 141, 242-246. https://doi.org/10.1016/j. sbspro.2014.05.042

Chacón-Beltrán, R. (2018). Vocabulary learning strategies outside the classroom context: what adults learn in a technology-based learner-centred environment. The Language Learning Journal, 46(5), 583-593. https://doi. org/10.1080/09571736.2018.1503135

Consejería de Educación de la Junta de Extremadura (2008). http://avanza. educarex.es

De Bot, K. (2004). The multilingual lexicon: Modelling selection and control. International Journal of Multilingualism 1 (1), 17-32. https://doi. org/10.1080/14790710408668176

De Groot, A. M. B., \& Keijzer, R. (2000). What is hard to learn is easy to forget: The roles of word concreteness, cognate status, \& word frequency in Foreign-Language vocabulary learning \& forgetting. Language Learning, 50(1), 1-56. https://doi.org/10.1111/0023-8333.00110

Dijkstra, T., Grainger, J., \& Van Heuven, W.J.B. (1999). Recognition of cognates and interlingual homographs: The neglected role of phonology. Journal of Memory and Language, 41, 496-518. https://doi.org/10.1006/ jmla.1999.2654

Dörnyei, Z. (2006). Individual differences in second language acquisition. AILA Review, 19, 42-68. https://doi.org/10.1075/aila.19.05dor

Dressler, C., Carlo, M.S., Snow, C., August, D., \& White, C. (2011). Spanish speaking students' use of cognate knowledge to infer the meaning of English words. Bilingualism: Language and Cognition, 14(2), 1-18. https:// doi.org/10.1017/S1366728910000519

Economically Active Population Survey (2018) https://www.ine.es/dyngs/INEbase/es/operacion.htm? $\mathrm{c}=$ Estadistica_C\&cid $=1254736176918 \& \mathrm{menu}=$ resultados\&idp $=1254735976595)$.

ELIA Mon. I, pp. 89-121ＤOI: http://dx.doi.org/10.12795/elia.mon.2019.i1.05 
Freed, B., Dewey, D., Segalowitz, N., \& Halter, R. (2004). The language contact profile. Studies in Second Language Acquisition, 26(2), 349-356. https:// doi.org/10.1017/S027226310426209X

Gardner, R. C. (1985). The Attitude/Motivation Test Battery: Technical Report. University of Western Ontario. Retrieved from http://publish.uwo. ca/ gardner/docs/AMTBmanual.pdf

Gardner, R. C. (2004). Attitude/Motivation Test Battery: International AMTB research project for English as a foreign language. (Translated into Spanish $\&$ Catalan by Mercè Bernaus).

Gobierno de Extremadura (2008). Order of 1st August 2008. Mérida: Consejería de Educación. [Available at: http://doe.gobex.es/pdfs/ doe/2008/1590o/08050291.pdf]

Google Chrome (2016). https://chrome.google.com/webstore/detail/the-cognatehighlighter-b/pepihjcfobjekmidhfnjjnoekpbnphdn

Griffiths, C. (2008). Strategies and good language learners. In C. Griffiths (Ed.) Lessons from good language learners (pp. 83-98).Cambridge: CambridgeUniversity Press.

Haastrup, K. (1991). Lexical inferencing procedures or talking about words: Receptive procedures in foreign language learning with special reference to English. Tübingen: Gunter Narr.

Helms-Park, R. \& Dronjic, V. (2016). Crosslinguistic lexical influence: cognate facilitation. In R. Alonso (Ed.), Crosslinguistic Influence (pp. 71-92). Multilingual Matters. https://doi.org/10.21832/9781783094837-007

Helms-Park, R., \& Perhan, Z. (2016). The role of explicit instruction in crossscript cognate recognition: The case of Ukrainian-speaking EAP learners. Journal of English for Academic Purposes, 21, 17-33. https://doi. org/10.1016/j.jeap.2015.08.005

Hernandez, A. E. (2013). The bilingual brain. Oxford, UK: Oxford University Press.

Holmes, J. \& Guerra Ramos, R. (1993). False friends and reckless guessers: Observing cognate recognition strategies. In T. Hauskin, M. Haunes, \& J.

ELIA Mon. I, pp. 89-121ＤOI: http://dx.doi.org/10.12795/elia.mon.2019.i1.05 
Coady (Eds.). Second language reading and vocabulary learning. Norwood, NJ: Ablex Publishing Corporation

Jarvis, S., \& Pavlenko, A. (2007). Crosslinguistic influence in language and cognition. New York: Routledge.

Jessner. U. (1999). Metalinguistic awareness in multilinguals: Cognitive aspects of third language learning. Language Awareness, 8, 201-209. https://doi. org/10.1080/09658419908667129

Kellerman, E. (1983). Now you see it, now you don't. In S. Gass \& L. Selinker (Eds.), Language transfer in language learning (pp. 112-134). Rowley, MA: Newbury House.

Knowles M., Holton, E. F., \& Swanson, R.A. (2005). The adult learner, sixth edition. Amsterdam: Elsevier.

Kroll, J.F., Michael, E., Tokowicz, N., \& Dufour, R. (2002). The development of lexical fluency as a second language. Second Language Research, 18(2), 137-171. https://doi.org/10.1191/0267658302sr201oa

Kroll, J. F., \& Sunderman, G. (2003). Cognitive processes in second language acquisition: The development of lexical and conceptual representations. In C. Doughty \& M. Long (Eds.), Handbook of second language acquisition (pp. 104-129).Cambridge, MA: Blackwell Publishers. https://doi. org/10.1002/9780470756492.ch5

Laufer, B. (1992). How much lexis is necessary for reading comprehension? In Arnaud, PJ.L. \& Béjoint, H. (Eds.), Vocabulary and applied linguistics (pp. 126-132). London: Macmillan.

Laufer, B. \& Goldstein, Z. (2004). Testing vocabulary knowledge: Size, strength, and computer adaptiveness. Language Learning, 54(3), 399-436. https:// doi.org/10.1111/j.0023-8333.2004.00260.x

Learn Spanish with Sebas (2017, September 13). 50 Nouns that Sound Similar in Spanish and English (Cognates). [Video file]. Retrieved from https://www. youtube. $\mathrm{com} /$ watch $\mathrm{v}=$ troDhqu $1 \mathrm{MJs} \&$ index $=3 \&$ list $=\mathrm{PLG} 33 \mathrm{oSmG}$ gZXYHDdww0qOjYyynUDxutGZF

ELIA Mon. I, pp. 89-121 DOI: http://dx.doi.org/10.12795/elia.mon.2019.i1.05 
Lemhöfer, K., Dijkstra, T. (2004). Recognizing cognates and interlexical homographs: Effects of code similarity in language specific and generalized lexical decision. Memory and Cognition, 32, 533-550. https://doi. org/10.3758/BF03195845

Lenneberg, E. H. (1967). The biological foundations of language: A summary. Hospital Practice, 2, 59-67.

Li, P. (2014). Bilingualism as a dynamic process. In B. MacWhinney, \& W. O'Grady (Eds.), Handbook of language emergence. John Wiley \& Sons, Inc.

Lightbown, P.M., \& Libben, G. (1984). The recognition and use of cognates by L2 learners. In R.W. Anderson (Ed.), Second Languages (pp. 393-417). Rowley, MA: Newbury House.

Lightbown, P. M., \& Spada, N. (2006). How languages are learned (3 ${ }^{\text {rd }}$ ed.). Oxford: Oxford University

Lirica-Learn Spanish with Music (2017, July 22). Spanish Cognates -12 Rules. [Video file]. Retrieved from https://www.youtube.com/ watch? $=5$ YocqSelZjs

Lotto, L. \& De Groot, A.M.B. (1998). Effects of learning method \& word type on acquiring vocabulary in an unfamiliar language. Language Learning, 48(1), 31-69. https://doi.org/10.1111/1467-9922.00032

Meara, P. (1980). Vocabulary acquisition: A neglected area of language learning. Language Teaching and Linguistics: Abstracts, 15 (4), 221-246. https://doi. org/10.1017/S0261444800008879

Meara, P. \& Jones, G. (1988). Vocabulary size as a placement indicator. In P. Grunwell (Ed.), Applied Linguistics in Society (pp.80-87). London: CILT.

Meara, P. (1990). A note on passive vocabulary. Second Language Research, 6 (2), $150-154$.

Meara, P. \& Milton, J. (2003). X_Lex: The Swansea Vocabulary Levels Test. Newbury: Express Publishing.

Meara, P., \& Miralpeix, I. (2017). Tools for researching vocabulary. Bristol, UK: Multilingual Matters.

ELIA Mon. I, pp. 89-121ＤOI: http://dx.doi.org/10.12795/elia.mon.2019.i1.05 
MECD (2013). Organic Law 8/2013 on the Improvement of the Quality of Education, of $9^{\text {th }}$ December. Madrid: Ministerio de Educación, Cultura $y$ Deporte. [Available at: http://www.boe.es/boe/dias/2013/12/10/pdfs/ BOE-A-2013-12886.pdf]

MECD (2017). Order 651/2017, of $5^{\text {th }}$ July. Madrid: Ministerio de Educación, Cultura y Deporte. [Available at: https://www.boe.es/boe/dias/2017/07/08/ pdfs/BOE-A-2017-7983.pdf]

Milton, J. (2009). Measuring second language vocabulary acquisition. Bristol; Buffalo; Toronto: Multiligual Matters.

Miralpeix, I. (2012). X_Lex and Y_Lex: A validation study. Paper presented at the $22^{\text {nd }}$ VARG Conference (Vocabulary Acquisition Research Group). Newtown, UK.

Miralpeix, I., \& Muñoz, C. (2018). Receptive vocabulary size and its relationship to EFL language skills. International Review of Applied Linguistics in Language Teaching, 56 (1), 1-24. https://doi.org/10.1515/iral-2017-0016

Nagy, W.E., García, G.E., Durgunoglu, A.Y., \& Hacin-Bhatt, B. (1993). SpanishEnglish bilingual students' use of cognates in English reading. Journal of ReadingBehavior,25,241-259.https://doi.org/10.1080/10862969009547816

Nash, R. (1997). NTC's Dictionary of Spanish cognates: Thematically organized. Lincolnwood, IL: NTC Publishing Group.

Nation, I. S. P., \& Beglar, D. (2007). A vocabulary size test. The Language Teacher, $31(7), 9-13$.

Peeters, D., Dijkstra, T., \& Grainger, J. (2013). The representation of identical cognates by late bilinguals: RT and ERP effects. Journal of Memory and Language, 68 (4), 315-332. https://doi.org/10.1016/j.jml.2012.12.003

Otwinowska-Kasztelanic, A. (2009). Raising awareness of cognate vocabulary as a strategy in teaching English to Polish adults. Innovation in Language Learning \& Teaching, 3(2), 131-147. https://doi.org/10.1080/17501220802283186

Otwinowska-Kasztelanic, A. (2016). Cognate vocabulary in language acquisition \& use: Attitudes, awareness \& activation. Bristol: Multilingual Matters.

Oxford, R. L. (1990). Language learning strategies: What every teacher should know. New York: Newbury House.

ELIA Mon. I, pp. 89-121 DOI: http://dx.doi.org/10.12795/elia.mon.2019.i1.05 
Oxford, R. L. (2003). Language learning styles and strategies: An overview. GALA, 1-25.

Plataforma Educativa Rayuela (2018) https://rayuela.educarex.es/

Ringbom, H. (1987). The role of the first language in foreign language learning. Clevedon: Multilingual Matters.

Ringbom, H. (2007). Cross-linguistic Similarity in Foreign Language Learning. Clevedon: Multilingual Matters.

Schepens, J., Dijkstra, T., \& Grootjen, F. (2012). Distributions of cognates in Europe as based on Levenshtein distance. Bilingualism: Language and Cognition, 15 (1), 157-166. https://doi.org/10.1017/S1366728910000623

Schmitt, N. (1997). Vocabulary learning strategies. In N. Schmitt \& M. McCarthy (Eds.), Vocabulary: Description, acquisition and pedagogy (pp. 199-227). Cambridge: Cambridge University Press.

Schmitt, N., Schmitt, D., \& Clapham, C. (2001). Developing and exploring the behaviour of two new versions of the Vocabulary Levels Test. Language Testing, 18 (1), 55-88. https://doi.org/10.1177/026553220101800103

Singleton, D. \& Ryan, L. (2004). Language acquisition: The age factor ( $2^{\text {nd }}$ ed.). Clevedon: Multilingual Matters.

Swam, M. (1997). The influence of the mother tongue on second language vocabulary acquisition and use. In N. Schmitt \& M. McCarthy (Eds.), Vocabulary: Description, acquisition and pedagogy (pp. 156-180). Cambridge: Cambridge University Press.

Tréville, M. (1996). Lexical learning and reading in L2 at the beginner level: the advantage of cognates. Canadian Modern Language Review, 53, 1-23. https://doi.org/10.3138/cmlr.53.1.173

UNEDAbierta (Producer). (2018). Empieza con el Inglés: Aprende las mil palabras más usadas y sus posibilidades comunicativas [MOOC]. Retrieved from https://iedra.uned.es/courses/course-v1:UNED+EmpIng_003+2018/info

Wilkins, D. A. (1972). Linguistics in language teaching. Cambridge: MFT Press.

WordReference (2009) www.wordreference.com

ELIA Mon. I, pp. 89-121ＤOI: http://dx.doi.org/10.12795/elia.mon.2019.i1.05 


\section{Appendix A}

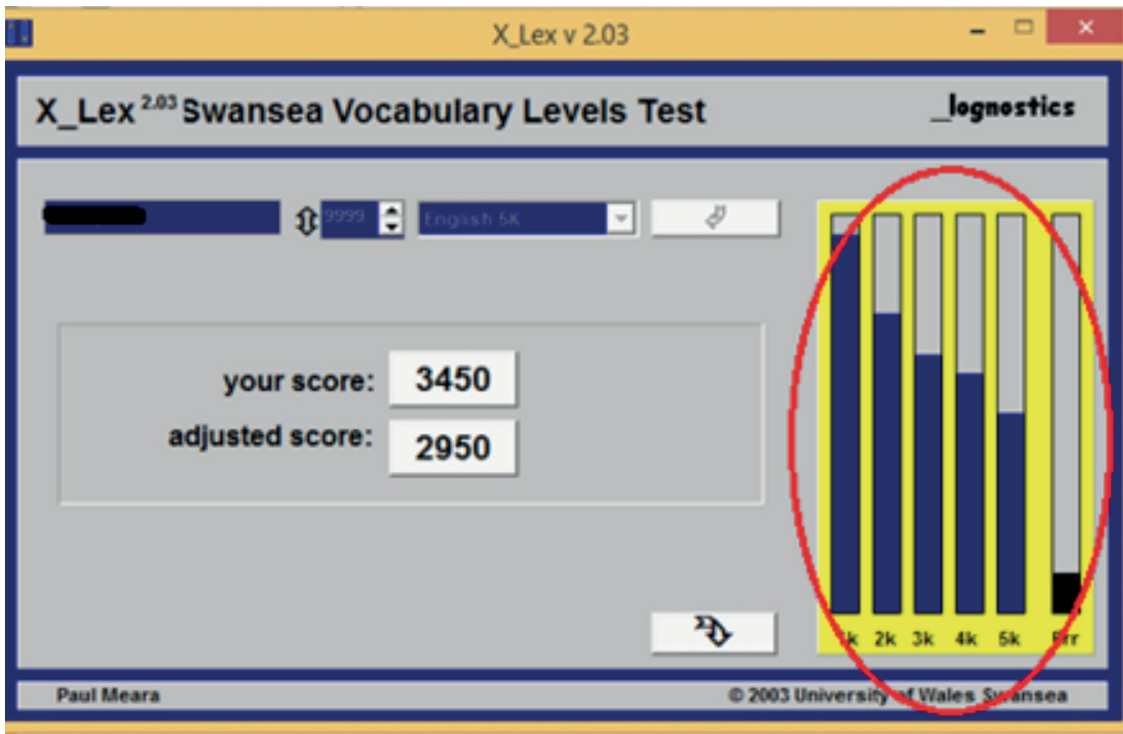

\section{Lexv203} - $\quad$ X

X_Lex ${ }^{200}$ Swansea Vocabulary Levels Test

Jegnestics

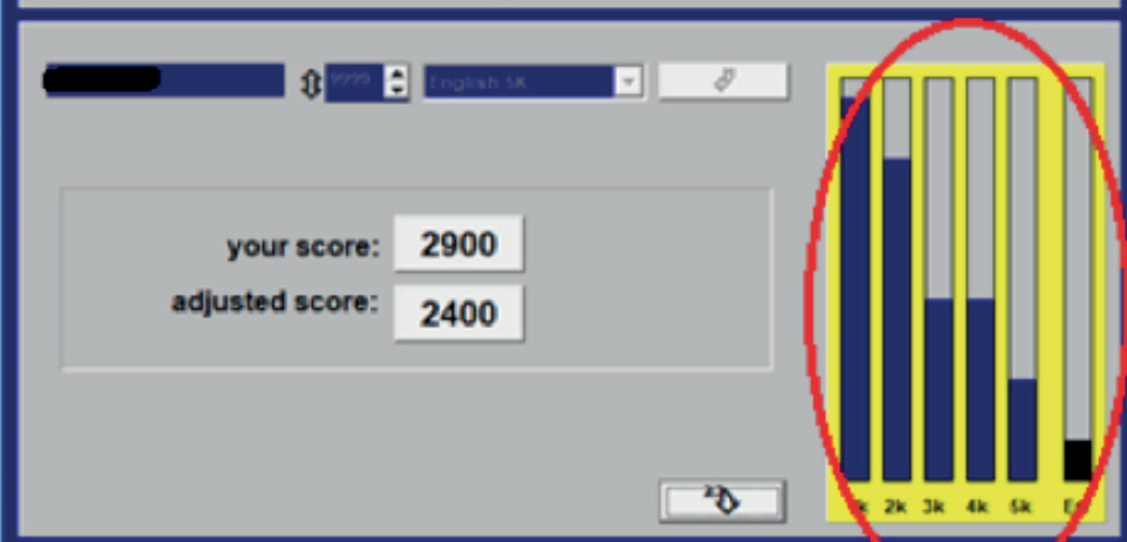

ELIA Mon. I, pp. 89-121～DOI: http://dx.doi.org/10.12795/elia.mon.2019.i1.05 


\section{Appendix B}

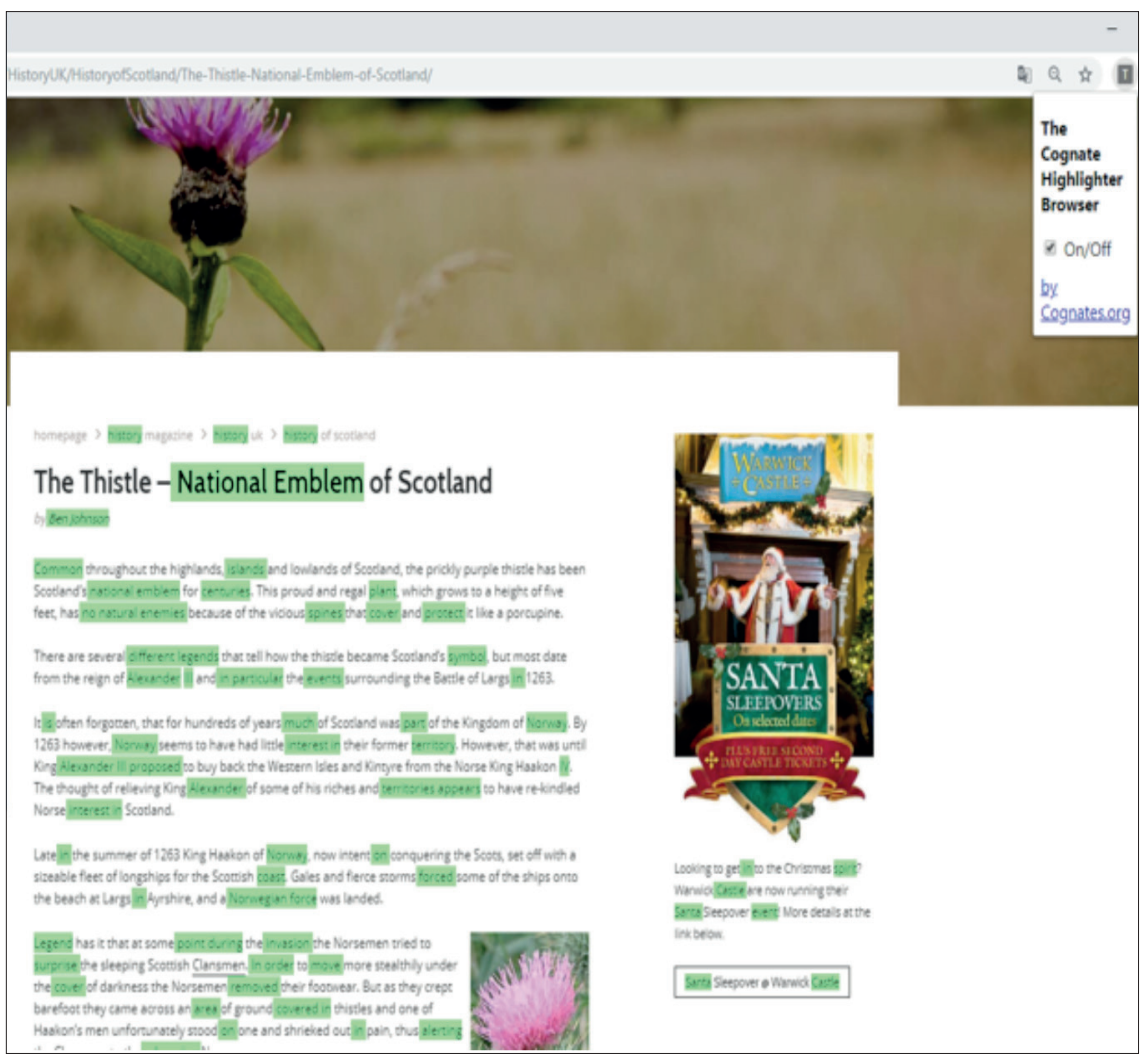

ELIA Mon. I, pp. 89-121ＤOI: http://dx.doi.org/10.12795/elia.mon.2019.i1.05 


\section{Appendix C}

\section{UTED COMA}

Empieza con el inglés: aprende las mil palabras más usadas... Módulo 1

Empieza con el inglés: aprende las mil palabras más usadas y sus posibilidades comunicativas: Módulo 1:

\section{Material Complementario 1: Primeros pasos}

1. Palabras idénticas al leer/escribir

2. Se les añade una terminación en español

3. Se quita la letra final y se añade una terminación en español

4. Patrones regulares inglés/español

5. Otras palabras muy similares en inglés/español

1. Palabras idénticas al leer/escribir

$\begin{array}{ll}\text { probable } & \text { probable } \\ \text { no } & \text { no } \\ \text { similar } & \text { similar } \\ \text { total } & \text { total } \\ \text { decision } & \text { decisión } \\ \text { idea } & \text { idea } \\ \text { region } & \text { región } \\ \text { social } & \text { social } \\ \text { central } & \text { central } \\ \text { local } & \text { local } \\ \text { area } & \text { área } \\ \text { club } & \text { club } \\ \text { animal } & \text { animal } \\ \text { final } & \text { final } \\ \text { hospital } & \text { hospital } \\ \text { doctor } & \text { doctor } \\ \text { personal } & \text { personal } \\ \text { plan } & \text { plan } \\ \text { in general } & \text { en general } \\ \text { particular } & \text { en particular } \\ \text { normal } & \text { normal } \\ \text { control } & \text { control } \\ \text { television } & \text { televisión } \\ \text { real } & \text { real } \\ \text { base } & \text { base }\end{array}$




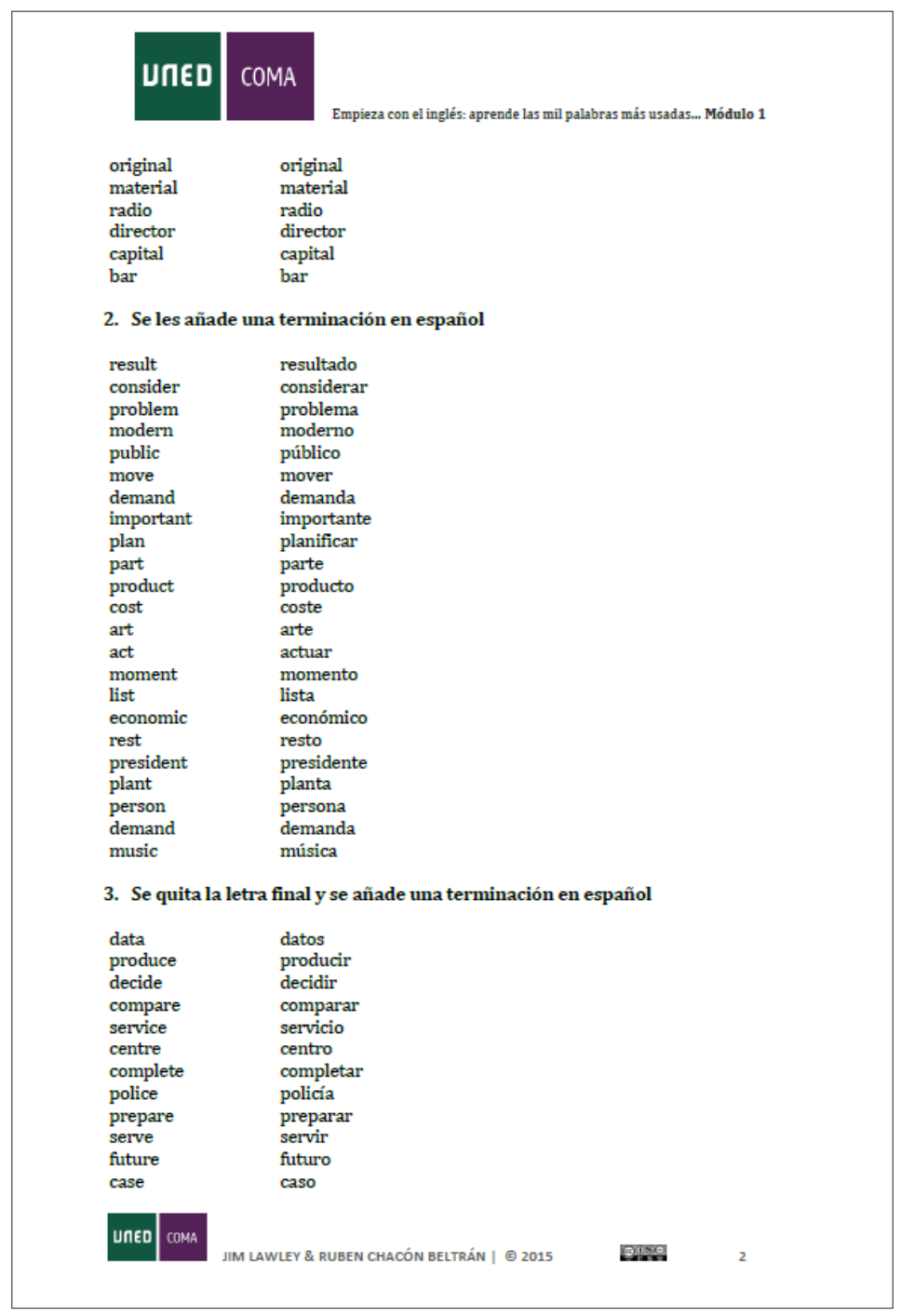

First version received: June, 2019 Final version accepted: September, 2019

ELIA Mon. I, pp. 89-121 DOI: http://dx.doi.org/10.12795/elia.mon.2019.i1.05 